\title{
Is Plato a Perfect Idealist?
}

\author{
Dr. Shanjendu Nath \\ M. A., M. Phil., Ph.D. Associate Professor Rabindrasadan Girls' College, Karimganj, Assam, India.
}

\begin{abstract}
Idealism is a philosophy that emphasizes on mind. According to this theory, mind is primary and objective world is nothing but an idea of our mind. Thus this theory believes that the primary thing that exists is spiritual and material world is secondary. This theory effectively begins with the thought of Greek philosopher Plato. But it is Gottfried Wilhelm Leibniz (1646-1716) who used the term 'idealism' when he referred Plato in his philosophy. Plato in his book 'The Republic' very clearly stated many aspects of thought and all these he discussed from the idealistic point of view. According to Plato, objective world is not a real world. It is the world of Ideas which is real. This world of Ideas is imperishable, immutable and eternal. These ideas do not exist in our mind or in the mind of God but exist by itself and independent of any mind. He also said that among the Ideas, the Idea of Good is the supreme Idea. These eternal ideas are not perceived by our sense organs but by our rational self. Thus Plato believes the existence of two worlds - material world and the world of Ideas. In this article I shall try to explore Plato's idealism, its origin, locus etc. and finally show whether he can be called a perfect idealist philosopher or not.
\end{abstract}

Key words: Dialectic, God, Good, Idea, Idealism.

\section{Introduction}

One of the fundamental problems in philosophy is the relation between subject and object. Here by subject is meant consciousness. Now the question arises which one is primary - subject or object? Centering round this question the entire world of philosophy is divided into two groups. One group holds the view that subject is primary and object is nothing but the ideas of our mind. The other group holds that there is an objective world independent of our mind. The former theory is known as idealism and the latter is known as realism. As the scope of this article is very limited so I shall not discuss with realism here.

According to idealism object has no extra mental reality. If object exists, it exists only as an idea of our mind. Thus this theory holds the view that the primary thing is spiritual or non material and material world is secondary. By saying so this theory is very close to the dogmas of religion and believes that the world is in time and space and it is created by God. This theory also regards consciousness in isolation from nature and thereby it mystifies both consciousness and process of cognition and by doing so it advocates skepticism and agnosticism. Thus the idealism believes that the reality that we know is something mental. Apart from mental construction it has no existence.

\section{The beginning of idealism in ancient philosophy}

It is generally admitted that in the western culture idealism is the oldest systematic philosophy and is effectively found in the philosophy of Plato (427-347) in ancient Greece. But it does not mean that there was no philosophy and philosophers before Plato. He is regarded as one of the most influential philosophers who developed philosophy of education.

But although idealism had its origin in Plato's philosophy but it is Gottfried WilhelmLeibniz (16461716), one of the great thinkers of the seventeenth and eighteenth centuries and is known as the last "universal genius" who first used the term 'idealism' in philosophy when he referred the philosophy of Plato.

Plato believed the existence of two worlds- visible world or the world of matter and the intelligible world or the world of ideas.The visible world is the world of becoming but the intelligible world is perfect and immutable world. The latter is also known as the world of ideas. The world in which we live is nothing but shadows of the perfect world. Thus the vision of the super-sensible truth which is called the theory of ideas is the basic feature of Platonic Philosophy.

\section{Sources of Ideas in Plato's Philosophy}

Plato did not tell us about the source of idea in his philosophy. It is Aristotle from whom we derive this hints. According to Aristotle, there are three different sources from which Plato derived the concept of ideas. These are the teachings of three Greek philosophers - Eleatics, Heracleitus and Socrates. In Plato's philosophy the concept of sphere of Becoming appears as the world of senses and this concept he borrowed from Heracleitus. He borrowed the Idea of a sphere of absolute Being from Eleatics and the doctrine of concept he 
borrowed from Socrates. Subsequently he identified Eleatics Being with that of Socratic concepts. Thus from this process Plato derived the theory of Ideas.

\section{Locus of Idea}

Plato said that ideas are not any particular thing but thought. Idea of horsedoes not mean any particular horse but universal horse. It is for this reason Ideas are called 'universal' in modern times. When it is said that idea is thought, it does not mean that ideas reside in human mind or in the mind of God. Ideas are in no way mind-dependent or subjective. These are rather objective and as such have reality by itself. It is eternal, imperishable and immutable, beyond space and time and apprehended only through reason.Idea exists by itself and that is why it is called substance.

The pre-Socratic philosophers attempted to explain nature with the help of mechanical and material causes only. They believed that the fundamental element of matter is four in number. These are- earth, water, fire and air. These elements are mechanically combined with each other and are true causes of things. But in contrast to this view Plato believed that in addition to these sensible elements there exists a supersensible something which is the cause of the sensible elements. Physical data cannot be explained with the help of physical elements. It needs ascending to the 'supersensible' which is called by him 'ideas'. By the term 'idea' Plato does not mean thought rather opposed to thought. It is that in which thought turns to when it thinks. Platonic idea is a 'being' and that being is absolutely true being. For Plato idea is not a logical concept, it is rather the essence and this essence is ontological.

Plato believed that search for truth should be the first and primary concern of human being. In support of this statement he put forwarded argument that truth is perfect and eternal and this is not found in the world of matter. Because material world is constantly changing and it is imperfect in its nature. He believed that in mathematics we have universal and eternal truth. None can deny that ' $2+2$ is equal to 4'; 'all points of a perfect circle are equidistant from the centre' are universally true. Thus all of us can be unanimous with regard to the universal truth that is found available in mathematics. But area of universal truth is vast and only a part of it is shared by mathematics. Other universal truths are also available in politics, society and education and a true philosopher must search for absolute truth in such area.

In his book The RepublicPlato further said that the highest point of the world of ideas is Good. All true knowledge is derived from this idea of Good. In contrast to the world of ideas, the world of matter is the world of sensory data and it is always changing. Thus changing world cannot be trusted. In order to proceed toward the highest idea, that is the idea of Good, people must keep himself free from concerning the material world.

\section{Place of Good and God in Plato's System}

In Plato's philosophy the Idea of Good is the highest idea with the help of which he explained the entire universe. All other ideas are finally explained with the Idea of Good. All things derive their perfection from the Idea of Good and therefore It is the source out of which the universe come into existence and to which things go back.

Now an obvious question is- what is the place of God in Plato's philosophy? He used the word God in the sense of one and many and therefore he is called both monotheist and polytheist. But although he believes the existence of many Gods yet he frequently referred to the existence of one supreme creator, controller and ruler of the world. Here another question is-what is the relation between this supreme God and ideas, particularly the Idea of Good? Are God and the Idea of Good one and the same thing or are they separate? If they are separate from each other then there seems to be different relation between these two.

1stly, Good is the creation of God. But if Good is created by God then Good is dependent on God and thereby Good cannot be the substance, as substance exists by itself without depending on others. Plato's whole philosophy is based on the conception that Ideas are ultimate and self existent. But if Good is created by God then substantiality of Idea is destroyed and with this his whole system is destroyed.

2ndly, the Idea of Good is the ground of the universe as a whole and therefore it is the ground of God. This means that the Idea of Good is supreme and God derives all its power from God and in that case Godexists only an appearance.

3rdly, both God and Good are equal in status and both are independent and ultimate realities. But this conception leads Plato's theory into inconsistent and hopeless dualism.

Thus from the above it is evident that none of the possible relation is acceptable and there is ample ground to suppose that both God and the Idea of Good are identical in Plato's philosophy and this God is not personal because his concept of Idea is not a person.

To realize this highest Good people must transcend the material world and this is possible by using the method of dialectic. It is dialectic method by which true knowledge can be attained from mere opinion. This dialectic is a process of thesis, anti-thesis and synthesis. All thinking begins with thesis but finding that it is not correct, its opposite is taken to be true. When its opposite is also found not to be true then both thesis and anti- 
thesis are combined which is called synthesis. Synthesis, according to Plato, is closer to truth. To acquire the process of dialectic one must have to maintain critical perspective. He must have knowledge in mathematics and involve in a long period of education. People who use this dialectic must have experience in it. Plato believed that the capacity for using dialectic begins after 30 years of age. Before this stipulated age bar students are not matured enough to have training on it.

Plato believed that we can move from the material world to the world of ideas and in this process dialectic is used as vehicle. There is a line of division between matter and idea and this line is crossed by dialectic. This crossing process is started in the world of matter and ends in the world of ideas. In this journey from the world of matter to the world of ideas, the brain, the tongue, gesture etc. are used. This world of idea is a world where the truth is discovered.

The theory of ideas or forms is of great importance in Plato's philosophy which his predecessors did not emphasize. This theory has two aspects - logical and metaphysical. The part which deals with the meaning of the general words is called logical. A large number of animals are there which are called 'cat'. The concept 'cat' is very much different from particular cat. An animal which participates in general nature that is found common to all cats is called 'cat'.

According to Plato, the world of idea is the real world and it is the world of type and clarity of knowledge. The material world is the dream world. He forbade us to make any exaggeration into the extent of separation between these two worlds. All material things derive their properties from the types. “........the point is (to repeat) that it is a firm part of Plato's theory that things gain their properties as a result of their connection with type. To see something as white is to see the presence of whiteness in it. In this sense, types are immanent in the world; and since types are the object of knowledge, then the world can become the object of knowledge. To believe that something is white, and to be able to justify that belief, is to have knowledge of it as white" . One who intends to know types and to have knowledge must have to withdraw himself from reliance on the senses and conventional attitude. A philosopher is free from the relative view point of this two world and he is capable of seeing the real things as they are. In the process of his work he needs no example of object from material world but can do with type alone.

Plato clearly stated that person who loves the 'vision of truth' is a philosopher. He also made a distinction between beautiful things and beauty in itself and said that persons who love beautiful things are not philosophers but a dreamer. He who loves beauty in itself is called a philosopher.

\section{Knowledge and Opinion}

In distinguishing knowledge and opinion Plato said that knowledge means knowledge of something and that something must exists. Knowledge cannot be mistaken and therefore it is infallible. But this cannot be ascribed to opinion. Opinion cannot be surely recognized as 'is' or 'is not'. It is not 'is' because in that case it will not be opinion but knowledge. Again, it cannot be 'is not' because it is an impossible. Hence it is both 'is' and 'is not.'

When Plato said 'knowledge', he meant knowledge of super sensible eternal world. This world is beyond our senses. But the world presented to our senses is called sensible world and we can have opinion about it. According to Plato all sensible objects are particular and bear contradictory characters of good and bad, beautiful and ugly, just and unjust etc. hence particulars are neither being nor non being. These are rather intermediate in between two and therefore objects not of knowledge but of opinion. Knowledge means knowledge of eternal, absolute and immutable entities what is absent in case of particular.

Plato's theory of 'ideas' or 'form' is partly logical and partly metaphysical. The part which deals with the meaning of general words is logical. When it is said that 'this is a cat' it means a particular cat different from other cats. A particular animal is called cat because it shares with the general nature of cat that are found common in all cats. But Plato said that by 'cat' he does not mean any particular cat but universal 'cattiness'. This universal 'cattiness' neither born nor dies as the particular cat. It is not found in a particular space or time and as such it is eternal. This analysis of meaning is the logical part in Plato's theory of ideas.

From the metaphysical point of view the 'cat' is an ideal cat. This ideal cat is created by God and as such it is unique. All particular cats imperfectly share with the nature of this ideal cat. As the particular cats are imperfect, so these are many in number. Their existence is not real but only apparent, where as the ideal cat is real.

There are different classes of objects and each class has different kinds of qualities of which some are essential qualities while some others are accidental. The essential qualities are common in each and every particular member of a class. For example, the quality 'cowness' is present in every particular cow. Again, the qualities colour, shape, size etc. vary in particular members of a class and hence these are accidental qualities.

${ }^{1}$ Quoted from Plato Republic, Translated by Robin Waterfield, P-xlviii 
Thus the essential qualities 'cowness' of a class 'cow' is called universals and individual member of a class who possesses this universal 'cowness' is called particulars.

\section{Conclusion:}

From the above discussion it is clear that Plato in his philosophy believes the reality of matter as well as eternal ideas. Matter is perceived by our body and sense organs and as such is imperfect and transitory but eternal ideas are directly perceived by our rational self. Thus from metaphysical and epistemological point of view Plato is a dualist.

Moreover, a perfect idealist philosopher never believes the external reality apart from mind. He believes that if any reality exists, it exists in the form of ideas in the mind. But Plato believes that idea exists not only in our mind but also as entities outside our minds and exists by their own right. The only reality is ideas and things we perceive are nothing but shadows of the reality. Modern idealists always striving to avoid this Platonic outlook. Thus in modern sense Plato cannot be called a perfect idealist philosopher.

\section{References:}

[1]. Annas, Julia: An Introduction to Plato's Republic, Oxford University Press, 1981.

[2]. Idealism - Wikipedia, The Free Encyclopedia

[3]. Interdisciplinary Encyclopedia of Religion and Science.

[4]. Jeremy Dunham, Lain Hamilton Grant and Sean Watson: Idealism: The History of a Philosophy, Acumen,2011.

[5]. R. F. Alfred Hoernle: Idealism as a Philosophy, George H Doran, New York, 1927.

[6]. Russell.B: History of Western Philosophy, Routledge , London and New York, 2006.

[7]. Santas, ed., Gerasimos:Understanding Plato's Republic, Oxford, Wiley Blackwell, 2010.

[8]. Stace,W.T.: A Critical History of Greek Philosophy, Macmillan and Co. Limited, London, 1953. 